\title{
Determinan Sosial Ekonomi Rumah Tangga dari Balita Stunting di Indonesia: Analisis Data Indonesia Family Life Survey (IFLS) 2014
}

\author{
Household Socio-Economic Determinants of Stunting Among Under Five Years Old Children \\ in Indonesia: Analysis of Indonesia Family Life Survey (IFLS) Data 2014
}

\author{
Dini Indrastuty ${ }^{1}$, Pujiyanto ${ }^{2}$
}

${ }^{1}$ Pascasarjana IImu Kesehatan Masyarakat, Fakultas Kesehatan Masyarakat, Universitas Indonesia ${ }^{2}$ Departemen Administrasi Kebijakan Kesehataan, Fakultas Kesehatan Masyarakat, Universitas Indonesia

\author{
Korespondensi: Dini Indrastuty \\ e-mail:diniindrastuty18@gmail.com
}

\begin{abstract}
Abstrak
Stunting merupakan masalah gizi kronis pada balita yang ditandai dengan tinggi badan yang lebih pendek dibandingkan dengan anak seusianya. Stunting pada balita memiliki risiko pada tingkat kecerdasan, kerentanan terhadap penyakit, menurunkan produktifitas yang dalam jangka panjang dapat menghambat pertumbuhan ekonomi. Ketika dewasa, anak yang menderita stunting rentan menderita penyakit tidak menular. Ini menyebabkan pengeluaran pemerintah dalam hal pembiayaan jaminan kesehatan nasional terus meningkat. Penelitian ini bertujuan untuk menganalisis determinan faktor sosial ekonomi rumah tangga dari balita stunting. Studi ini menggunakan data sekunder Indonesia Family Life Survey (IFLS) tahun 2014 dengan desain studi cross sectional dan aplikasi model logit ekonometrik. Jumlah observasi yang menjadi sampel analisis dalam penelitian ini sebesar 3.794 balita dalam skala nasional. Hasil penelitian menunjukkan kejadian balita stunting memiliki hubungan signifikan dengan status pekerjaan ibu, tempat tinggal, sanitasi dan status ekonomi. Ibu yang lebih banyak meluangkan waktu dan memperhatikan gizi anak, tempat tinggal balita yang dapat menjangkau fasilitas layanan kesehatan, akses sanitasi yang baik, status ekonomi keluarga, intervensi pemerintah yang tepat, dan peran lintas sektor dan tatanan masyarakat berdampak dalam penanganan masalah stunting di Indonesia.
\end{abstract}

Kata kunci: balita, stunting, sosial, ekonomi, logit

\begin{abstract}
Stunting is a chronic nutritional problem in infants characterized by shorter stature compared to their age. Stunting in toddlers has risk at the level of intelligence, vulnerability to disease, lowering productivity which in the long run can hamper economic growth. When adults, children who suffer from stunting are prone to non-communicable diseases. This causes government spending in terms of financing national health insurance to continue to increase. This study aims to analyze the determinants of household socioeconomic factors of stunting toddlers. It used the secondary data of the Indonesian Family Life Survey (IFLS) in 2014 with cross-sectional study design and the application of an econometric logit model. The number of observations as a sample in this study amounted to 3,794 toddlers on a national scale. The results showed the incidence of stunting toddlers had a significant relationship with the employment status of mothers, shelter, sanitation and economic status. Mothers who spend more time and pay attention to child nutrition, toddlers who can reach health care facilities, access to good sanitation, family economic status, proper government intervention, and the role of cross-sector and community order have an impact on the handling of stunting problems in Indonesia.
\end{abstract}

Keywords: toddlers, stunting, social, economic, logit

\section{Pendahuluan}

Masalah gizi kurang masih banyak ditemukan di berbagai kelompok masyarakat di beberapa negara berkembang, khususnya Indonesia. Salah satu masalah kurang gizi yang harus mendapatkan perhatian adalah stunting (pendek dan sangat pendek) yang terjadi pada balita. Masalah gizi, khususnya anak pendek, menghambat perkembangan anak muda, dengan dampak negatif yang akan berlangsung dalam kehidupan selanjutnya (UNICEF 2012).

Stunting adalah gangguan pertumbuhan dan perkembangan yang dialami anak-anak dari gizi buruk, infeksi berulang, dan stimulasi psikososial yang tidak memadai yang ditunjukkan dengan nilai z-score tinggi badan menurut usia $(\mathrm{TB} / \mathrm{U})<-2$ standar deviasi berdasarkan standar WHO (WHO 2012)

Secara global jumlah anak stunting di bawah usia 5 tahun sebanyak 165 juta anak atau 26\%. Asia merupakan wilayah kedua setelah Afrika yang memiliki prevalensi anak stunting tertinggi yaitu $26,8 \%$ atau 95,8 juta anak. Sedangkan prevalensi anak stunting untuk wilayah Asia Tenggara adalah 
$27,8 \%$ atau 14,8 juta anak. Retardasi pertumbuhan atau stunting pada anak-anak di negara berkembang terjadi terutama sebagai akibat dari kekurangan gizi kronis dan penyakit infeksi yang mempengaruhi 30\% dari anak-anak usia di bawah lima tahun (UNSCN, 2004). Berdasarkan hasil data Riset Kesehatan Dasar 2018 proporsi status gizi sangat pendek sebesar 11,5\% dan status gizi pendek sebesar 19,3\% (Riskesdas 2018). Prevalensi stunting di Indonesia lebih tinggi daripada negara-negara di Asia Tenggara (WHO, 2016).

Stunting pada balita berdampak terhadap tingkat kecerdasan, kerentanan terhadap penyakit, menurunkan produktifitas dan kemudian menghambat pertumbuhan ekonomi, meningkatkan kemiskinan dan ketimpangan (TNP2K, 2018). Stunting dapat menghambat pertumbuhan ekonomi dan produktivitas pasar kerja. Bukti yang ditunjukkan diantaranya hilangnya 11\% GDP dan mengurangi pendapatan pekerja dewasa hingga 20\%. Stunting juga memperburuk kesenjangan/ inequality yang menyebabkan pengurangan $10 \%$ dari total pendapatan seumur hidup dan menimbulkan kemiskinan antar generasi (World Bank Group 2016)

Rendahnya pendidikan ibu yang berkaitan dengan pengetahuan tentang gizi bayi, sangat mempengaruhi kejadian balita stunting. Ibu dengan tingkat pendidikan rendah berisiko 5,1 kali lebih besar memiliki anak stunting (Atikah, 2014). Anak stunting lebih banyak terjadi pada anak yang memiliki ibu dengan tingkat pendidikan di bawah 9 tahun (Lestari, 2014). Meningkatnya jumlah wanita yang bekerja di luar rumah juga mempengaruhi jumlah kejadian balita stunting. Persentase gizi kurang lebih tinggi pada balita dari ibu yang bekerja sebagai petani/nelayan, buruh harian, dan pengrajin/ TKI dibandingkan ibu yang tidak bekerja (Devi, 2010).

Beberapa faktor internal keluarga dan faktor lingkungan juga ikut memberikan dampak pada balita stunting seperti jenis kelamin balita, tempat tinggal, sarana sanitasi pembuangan kotoran manusia dan status ekonomi. Pada sanitasi lingkungan, jenis jamban yang tidak layak (bukan leher angsa) mempunyai kecenderungan untuk menderita stunting 1,3 kali lebih tinggi dibandingkan baduta yang mempunyai jamban layak (Adiyanti, 2014). Tujuan dari penelitian ini adalah untuk mengetahui determinan faktor-faktor sosial ekonomi rumah tangga yang mempengaruhi kejadian balita stunting di Indonesia.

\section{Metodologi Penelitian}

Penelitian ini merupakan analisis data sekunder menggunakan data Indonesia Family Life Survey (IFLS) tahun 2014 yaitu sebuah survei data panel yang dilakukan oleh SurveyMETER dan RAND Coorperation dengan desain cross sectional. Responden penelitian adalah bayi usia 0-59 bulan sebanyak 3.794 balita. Pengukuran antropometri menghasilkan z-score diolah menggunakan Zanthro (Vidmar, 2004) menurut TB/U (tinggi badan per umur) pada software STATA 15.

Uji analisis yang digunakan adalah analisis univariat, bivariat dan uji logistic regression (logit) dengan estimator Maximum Likelihood. Model Binary Logit dipilih karena model dengan variable terikat berskala pengukuran nominal atau ordinal hanya terdiri dari dua kategori pilihan kualitatif (Junaidi 2015). Uji asumsi logit digunakan untuk melihat probabilitas variabel-variabel independen terhadap kejadian balita stunting dan melihat arah positif dan negatif untuk menyatakan bahwa setiap perubahan satu unit variabel independent akan menaikkan atau menurunkan kemungkinan kejadian balita stunting sebesar nilai koefisien masing-masing variabel independen.

Spesifikasi model ekonometrik dan deskripsi data yang digunakan dalam penelitian ini adalah :

$Y=\beta_{0}+\beta_{1} X_{1}+\beta_{2} X_{2}+\beta_{3} X_{3}+\beta_{4} X_{4}+\beta_{5} X_{5}+\beta_{6} X_{6}$

Keterangan:

$\begin{array}{ll}\mathrm{Y} & =\text { Kejadian balita stunting } \\ \beta_{0} & =\text { Konstanta } / \text { intersep } \\ \beta_{1}, \beta_{2}, \beta_{3}, \beta_{4}, \beta_{5}, \beta_{6} & =\text { Parameter } \\ \mathrm{X}_{1} & =\text { Pendidikan ibu } \\ \mathrm{X}_{2} & =\text { Jenis kelamin } \\ \mathrm{X}_{3} & =\text { Status Pekerjaan ibu } \\ \mathrm{X}_{4} & =\text { Tempat tinggal } \\ \mathrm{X}_{5} & =\text { Sanitasi } \\ \mathrm{X}^{5} & =\text { Status ekonomi } \\ \mu_{i} & =\text { Error term }\end{array}$

\section{Hasil Penelitian \\ Analisis Univariat}

Hasil analisis univariat menggambarkan sebaran frekuensi dan persentase dari terjadinya balita stunting dan sosiodemografi responden (Tabel 1). Tabel 1 menunjukkan bahwa jumlah bayi usia 0-59 bulan yang mengalami stunting di Indonesia 
Tabel 1. Distribusi Balita Stunting dan Sosiodemografi Responden di Indonesia

\begin{tabular}{|c|c|c|c|c|c|c|}
\hline Variabel & $\begin{array}{l}\text { Frekuensi } \\
\text { (n) }\end{array}$ & $\begin{array}{l}\text { Persentase } \\
\text { (\%) }\end{array}$ & Mean & SD & Min & $\operatorname{Max}$ \\
\hline \multicolumn{7}{|l|}{ Variabel Dependen } \\
\hline Balita stunting & 1.226 & 32,31 & 0,676 & 0,468 & 0 & 1 \\
\hline Balita tidak stunting & 2.568 & 67,69 & & & & \\
\hline \multicolumn{7}{|l|}{ Variabel Independen } \\
\hline \multicolumn{7}{|l|}{ Pendidikan Ibu } \\
\hline Rendah (SD-SMP) & 2.039 & 53,74 & 1,462 & 0,498 & 1 & 2 \\
\hline Tinggi (SMA-PT) & 1.755 & 46,26 & & & & \\
\hline Jenis Kelamin Balita & & & 0,485 & 0,499 & 0 & 1 \\
\hline Laki-laki & 1.954 & 51,50 & & & & \\
\hline Perempuan & 1.840 & 48,50 & & & & \\
\hline Status Pekerjaan & & & 0,342 & 0,475 & 0 & 1 \\
\hline Tidak Bekerja & 2.495 & 65,76 & & & & \\
\hline Bekerja & 1.299 & 34,24 & & & & \\
\hline Tempat Tinggal & & & 0,567 & 0,495 & 0 & 1 \\
\hline Kota & 2.151 & 56,69 & & & & \\
\hline Desa & 1.643 & 43,31 & & & & \\
\hline Sanitasi & & & 0,743 & 0,437 & 0 & 1 \\
\hline Sarana BAB baik & 2.822 & 74,38 & & & & \\
\hline Sarana BAB tidak baik & 972 & 25,62 & & & & \\
\hline \multicolumn{7}{|l|}{ Status Ekonomi } \\
\hline Kuintil 1 & 760 & 20,03 & $355.163,2$ & $80.418,03$ & $85.583,3$ & $468.000,0$ \\
\hline Kuintil 2 & 758 & 19,98 & $559.008,5$ & $54.274,94$ & $468.010,4$ & 652729.1 \\
\hline Kuintil 3 & 759 & 20,01 & $758.888,9$ & $58.608,26$ & $653.050,0$ & $861.812,5$ \\
\hline Kuintil 4 & 759 & 20,01 & $1.013 .003,0$ & $100.254,10$ & $862.016,6$ & $1.207 .512,0$ \\
\hline Kuintil 5 & 758 & 19,98 & $1.911 .905,0$ & $972.832,60$ & $1.207 .708,0$ & $1.700 .000,0$ \\
\hline
\end{tabular}

sebanyak 1.226 balita $(32,31 \%)$ dari total responden 3.794 balita. Kelompok pendidikan yang ditempuh ibu paling banyak terdapat pada kelompok pendidikan rendah (SD-SMP) yaitu sebanyak 2.039 ibu $(53,74 \%)$ dan jenis kelamin bayi yang menjadi responden paling banyak adalah balita laki-laki yaitu sebanyak 1.954 bayi $(51,50 \%)$.

Status pekerjaan ibu yang paling banyak adalah tidak bekerja yaitu 2.495 ibu (65,76\%). Responden lebih banyak bertempat tinggal di kota yaitu 2.151 responden (56,69\%). Sebagian besar responden memiliki sarana sanitasi $B A B$ yang baik yaitu 2.822 responden $(74,38 \%)$ dan memiliki status ekonomi yang berada di kuintil 1 yaitu sebanyak 760 responden (20,03\%).

Pada tahun 2014 kejadian balita stunting di Indonesia yaitu sebesar 67,6\%. Gambaran variabel independen diperoleh bahwa rata-rata ibu mene- mpuh pendidikan rendah (SD dan SMP) sebesar 46,2\%. Variabel jenis kelamin balita sebagai responden yaitu rata-rata sebesar $48,5 \%$ adalah bayi perempuan. Ibu dengan status bekerja yaitu sebesar $34,2 \%$. Variabel tempat tinggal lebih dari setengah jumlah responden yaitu sebesar 56,7\% responden tinggal di wilayah desa. Responden yang memiliki sanitasi berupa sarana BAB yang baik jumlahnya melebihi dari setengah jumlah responden yaitu sebesar 74,3\%. Responden dengan status ekonomi di kuintil 1 memiliki rata-rata pengeluaran rumah tangga paling rendah sebesar Rp. 355.163,20 per individu per bulan, sedangkan responden dengan status ekonomi di kuintil 5 memiliki rata-rata pengeluaran rumah tangga paling tinggi yaitu sebesar Rp. 1.911.905,00 per individu per bulan.

\section{Analisis Bivariat}

Analisis bivariat menampilkan hubungan antara 
Tabel 2. Distribusi Kejadian Balita Stunting berdasarkan Karakteristik Sosial Demografi

\begin{tabular}{|c|c|c|c|c|c|c|c|}
\hline \multirow{3}{*}{ Variabel } & \multicolumn{4}{|c|}{ Balita Stunting } & \multirow{3}{*}{$P$ value } & \multirow{2}{*}{\multicolumn{2}{|c|}{ Total }} \\
\hline & \multicolumn{2}{|c|}{ Stunting } & \multicolumn{2}{|c|}{ Tidak Stunting } & & & \\
\hline & $\mathbf{n}$ & $\%$ & $\mathbf{n}$ & $\%$ & & $\mathbf{n}$ & $\%$ \\
\hline \multicolumn{8}{|l|}{ Pendidikan Ibu } \\
\hline Rendah (SD-SMP) & 718 & 35,21 & 1.321 & 64,79 & 0,195 & 2.039 & 100 \\
\hline Tinggi (SMA-PT) & 508 & 28,95 & 1.247 & 71,05 & & 1.755 & 100 \\
\hline \multicolumn{8}{|l|}{ Jenis Kelamin Balita } \\
\hline Laki-laki & 652 & 33,47 & 1.302 & 66,63 & 0,265 & 1.954 & 100 \\
\hline Perempuan & 574 & 31,20 & 1.266 & 68,80 & & 1.840 & 100 \\
\hline \multicolumn{8}{|l|}{ Status Pekerjaan } \\
\hline Tidak Bekerja & 838 & 33,59 & 1.657 & 66,41 & $0,059^{\star}$ & 2.495 & 100 \\
\hline Bekerja & 388 & 29,87 & 911 & 70,13 & & 1.299 & 100 \\
\hline \multicolumn{8}{|l|}{ Tempat Tinggal } \\
\hline Kota & 613 & 28,50 & 1.538 & 71,50 & $0,000^{*}$ & 2.151 & 100 \\
\hline Desa & 613 & 37,31 & 1.030 & 62,69 & & 1.643 & 100 \\
\hline \multicolumn{8}{|l|}{ Sanitasi } \\
\hline Sarana BAB baik & 829 & 29,38 & 1.993 & 70,62 & $0,000^{*}$ & 2.822 & 100 \\
\hline Sarana BAB tidak baik & 397 & 40,84 & 575 & 59,16 & & 972 & 100 \\
\hline \multicolumn{8}{|l|}{ Status Ekonomi } \\
\hline Kuintil 1 & 292 & 38,42 & 468 & 61,58 & $0,002^{*}$ & 760 & 100 \\
\hline Kuintil 2 & 256 & 33,77 & 502 & 66,23 & $0,074^{\star}$ & 758 & 100 \\
\hline Kuintil 3 & 256 & 33,73 & 503 & 66,27 & $0,036^{\star}$ & 759 & 100 \\
\hline Kuintil 4 & 229 & 30,17 & 530 & 69,83 & 0,206 & 759 & 100 \\
\hline Kuintil 5 & 193 & 25,46 & 565 & 74,54 & - & 758 & 100 \\
\hline
\end{tabular}

Tabel 3. Hasil Uji Asumsi Logit Variabel Balita Stunting terhadap Variabel Independen

\begin{tabular}{lccccc}
\hline \multicolumn{1}{c}{ Variabel } & \multicolumn{5}{c}{ Logit } \\
\cline { 2 - 6 } & $\begin{array}{c}\text { Koefisien } \\
\text { (Robust) }\end{array}$ & SE & Marginal Effect & SE & Odd Ratio \\
\hline Pendidikan Ibu & 0.097 & 0.075 & 0.021 & 0.016 & 1.10 \\
Jenis Kelamin Balita & 0.078 & 0.070 & 0.017 & 0.015 & 1.08 \\
Status Pekerjaan & $0.141^{*}$ & 0.075 & 0.030 & 0.016 & 1.15 \\
Tempat Tinggal & $0.281^{*}$ & 0.073 & 0.061 & 0.016 & 1.32 \\
Sanitasi & $0.358^{*}$ & 0.082 & 0.080 & 0.018 & 1.43 \\
quintile_1 & $0.361^{*}$ & 0.120 & 0.081 & 0.027 & 1.43 \\
quintile_2 & $0.210^{*}$ & 0.119 & 0.046 & 0.027 & 1.23 \\
quintile_3 & $0.244^{*}$ & 0.117 & 0.054 & 0.026 & 1.27 \\
quintile_4 & 0.147 & 0.115 & 0.032 & 0.025 & 1.15 \\
Constant & -1.349 & 0.168 & -- & -- & \\
Observation & 3.794 & -- & -- & -- & \\
R-Squared & 0,017 & -- & -- & - & \\
\hline Standard errors in parentheses & & & &
\end{tabular}


satu variabel independen dengan satu variabel dependen menggunakan Uji Kai Kuadrat (Chi Square). Tabel 2 menunjukkan ibu yang menempuh pendidikan rendah (SD dan SMP) lebih banyak mengalami kejadian balita stunting yaitu 35,21\% dibandingkan dengan ibu yang menempuh pendidikan tinggi yaitu $28,95 \%$. Balita dengan jenis kelamin laki-laki lebih banyak mengalami kejadian balita stunting yaitu 33,47\% dibandingkan dengan balita dengan jenis kelamin perempuan yaitu $32,20 \%$. Status ibu yang tidak bekerja lebih banyak mengalami kejadian balita stunting yaitu sebesar 33,59\% pendidikan dengan ibu yang bekerja yaitu $29,87 \%$.

Balita yang mengalami kejadian stunting lebih banyak memiliki tempat tinggal di desa yaitu sebanyak 37,31\% dibandingkan dengan balita yang tinggal di kota yaitu sebesar 28,50\%. Responden yang memiliki status ekonomi di kuintil satu lebih banyak mengalami kejadian balita stunting yaitu 38,42\% dibandingkan dengan responden yang memiliki status ekonomi di kuintil lainnya.

\section{Uji Asumsi Logit}

Dari hasil pengolahan data, didapatkan model analisis logit sebagai berikut:

$P($ stunting $=1 \mid X)=$

$-1.349+0.097$ pendidikan ibu $+0,078 \mathrm{sex}+0,141$ status_kerja $+0,281$ tmpt_tinggal $+0,358$ sanitasi $+0,361$ quintile_1 + 0.210 quintile_2 + 0.244 quintile_3 + 0.147 quintile_4

Hasil uji asumsi Logit dari persamaan diatas menunjukkan bahwa:

a. Ibu dengan pendidikan rendah mempunyai peluang memiliki balita stunting lebih tinggi 9,7\% dibandingkan ibu dengan pendidikan tinggi.

b. Balita dengan jenis kelamin laki-laki lebih tinggi berpeluang mengalami kejadian balita stunting sebesar 7,8\% dibandingkan balita berjenis kelamin perempuan.

c. Status ibu yang tidak bekerja lebih tinggi berpeluang mengalami kejadian balita stunting sebesar 14,1\% dibandingkan ibu yang bekerja.

d. Keluarga dengan tempat tinggal di desa lebih tinggi berpeluang mengalami kejadian balita stunting sebesar 28,1\% dibandingkan keluarga yang bertempat tinggal di kota.

e. Rumah tangga dengan sanitasi sarana pembuangan kotoran manusia yang tidak baik lebih tinggi berpeluang mengalami kejadian balita stunting sebesar 35,8\% dibandingkan rumah tangga dengan sanitasi sarana pembuangan kotoran manusia baik.

f. Individu dengan status ekonomi yang berada di kuintil satu lebih tinggi berpeluang mengalami kejadian balita stunting sebesar 36,1\% dibandingkan individu dengan status ekonomi yang berada di kuintil lainnya.

\section{Pembahasan}

Penelitian ini menunjukkan jumlah kejadian balita stunting di Indonesia menurut data survey IFLS tahun 2014 yaitu 32,44\%, belum memenuhi target RPJMN (Rencana Pembangunan Jangka Menengah Nasional) yaitu penurunan prevalensi stunting dari status awal 32,9\% di tahun 2013 menjadi 28,0\% pada tahun 2019 (Kemenkes 2015).

\section{Status Pekerjaan Ibu}

Hasil penelitian menunjukkan terdapat pengaruh yang signifikan antara status pekerjaan ibu dengan peluang terhadap kejadian balita stunting. Ibu yang tidak bekerja mempunyai peluang mengalami kejadian balita stunting 1,15 kali lebih tinggi daripada ibu yang bekerja. Ibu yang tidak bekerja lebih banyak memiliki waktu dalam memberikan perhatian perihal kesehatan dan gizi balita di rumah. Sedangkan ibu yang mempunyai pekerjaan tidak lagi dapat memberikan perhatian penuh terhadap anak balitanya karena kesibukan dan beban kerja yang ditanggungnya sehingga menyebabkan kurangnya perhatian ibu dalam menyiapkan hidangan yang sesuai untuk balitanya (Suhardjo, 1989 dalam (Anisa, 2012).

\section{Tempat Tinggal}

Tempat tinggal sebagai domisili balita mempunyai hubungan signifikan yang berpeluang terhadap kejadian balita stunting. Keluarga yang memiliki tempat tinggal di desa mempunyai peluang mengalami kejadian balita stunting 1,32 kali lebih tinggi daripada keluarga yang tinggal di kota. Akses untuk memperoleh fasilitas kesehatan seperti puskesmas atau rumah sakit dan pengetahuan tentang gizi yang minim di wilayah desa termasuk salah satu faktor penyebab kejadian balita stunting. Hal ini sesuai dengan penelitian sebelumnya bahwa sampel yang tinggal di wilayah kota memiliki efek protektif atau risiko lebih rendah 32 persen terhadap stunting dibandingkan dengan anak yang tinggal di perdesaan (Rosha., et al 2012). Program pemerintah 
Fokus Cegah Stunting di 100 Kabupaten/Kota mulai berjalan tahun 2018 dengan program PMT (Pemberian Makanan Tambahan) di daerah yang memiliki angka stunting tinggi. (Kemenkes, 2018). Keterjangkauan akses layanan kesehatan di daerah pedesaan menjadi salah satu target intervensi penanganan stunting yang menjadi tanggung jawab Kementerian Kesehatan RI (Kemenkeu, 2018)

\section{Sanitasi}

Sanitasi sarana pembuangan kotoran manusia mempunyai hubungan signifikan yang mempengaruhi peluang terhadap kejadian balita stunting. Rumah tangga yang memiliki sanitasi sarana pembuangan kotoran manusia yang tidak baik mempunyai peluang mengalami kejadian balita stunting 1,43 kali lebih tinggi daripada rumah dengan sanitasi sarana pembuangan kotoran manusia yang baik. Hasil penelitian ini sesuai dengan studi yang yang menunjukkan bahwa sanitasi lingkungan seperti jenis jamban yang digunakan, sumber air terlindung dan sumber air mudah didapat mempunyai hubungan bermakna dengan kejadian baduta stunting (Adiyanti, 2014).

Minimnya sarana sanitasi digambarkan dari hasil penelitian bahwa 1 dari 5 rumah tangga masih $\mathrm{BAB}$ di ruang terbuka (Kemenkeu, 2018). Saat ini,pembinaan program STBM (Sanitasi Total Berbasis Masyarakat) yang merupakan pendekatan untuk mengubah perilaku higienis dan saniter melalui pemberdayaan masyarakat dengan cara pemicuan terus digalakkan Kemenkes sebagai salah satu intervensi gizi spesifik penanganan masalah stunting (Kemenkeu, 2018). Pendekatan tidak langsung atau sensitif seperti penyediaan air bersih, fasilitas sanitasi serta layanan kesehatan tercakup lewat Dana Desa (Kemendes, 2017)

\section{Status Ekonomi}

Dalam penelitian ini status ekonomi responden pada posisi kuintil satu, kuintil dua dan kuintil tiga mempunyai hubungan signifikan yang mempengaruhi peluang terhadap kejadian balita stunting dengan p-value sebesar $0,007<0,1$. Individu yang berada di kuintil satu mempunyai peluang mengalami kejadian balita stunting 1,43 kali lebih tinggi daripada individu di kuintil lainnya. Hal ini sejalan dengan penelitian sebelumnya yang menunjukkan hubungan bermakna antara pendapatan keluarga dan pendidikan ibu dengan kejadian stunting pada balita (Fikrina, et al, 2017). Selain itu sebuah penelitian menyatakan bahwa kejadian stunting yang tinggi terdapat pada pendapatan rumah tangga rendah dan menunjukkan adanya hubungan dengan kejadian stunting (Wiyogowati, 2012). Pendapatan yang rendah akan menghambat individu untuk mengkonsumsi nutrisi bergizi (Hasibuan, et al, 2014). Hal tersebut juga sesuai dengan pendapat Hardiansyah, 1985 yang mengatakan bahwa dengan meningkatnya pendapatan berarti memperbesar peluang untuk membeli pangan dengan kuantitas dan kualitas yang lebih baik. Sebaliknya penurunan pendapatan akan menyebabkan penurunan dalam hal kualitas dan kuantitas pangan yang dibeli (Faradina. 2018). Apabila pendapatan meningkat, pola konsumsi akan lebih beragam sehingga konsumsi pangan yang bernilai gizi tinggi juga akan meningkat (Yudaningrum, 2011).

\section{Pendidikan Ibu}

Berdasarkan penelitian ini, pendidikan ibu tidak signifikan terhadap peluang kejadian balita stunting karena $p$ value 0,195 >0,1. Ibu yang memiliki tingkat pendidikan rendah tidak selalu memiliki balita dengan masalah stunting yang lebih banyak daripada ibu dengan tingkat pendidikan lebih tinggi. Hal ini dikarenakan tingkat pendidikan ibu merupakan faktor tidak langsung yang mempengaruhi stunting (Rukmana, et al 2016). Hal ini sejalan dengan penelitian sebelumnya yang menunjukkan tidak ada hubungan antara pendidikan ibu dengan stunting pada balita (Ni'mah., et al 2015). Penelitian lainnya juga menyatakan hal yang sama, bahwa tidak ada hubungan antara tingkat pendidikan ibu dengan stunting pada balita (Anindita, 2012).

\section{Jenis Kelamin Balita}

Jenis kelamin balita juga menjadi variabel yang tidak signifikan terhadap peluang tidak mengalami kejadian balita stunting. Sebagian besar balita yang mengalami stunting memiliki jenis kelamin laki-laki dengan p-value sebesar 0,265 >0,1. Beberapa yang menjadi penyebabnya adalah perkembangan motorik kasar anak laki-laki lebih cepat dan beragam sehingga membutuhkan energi lebih banyak. Hal ini sejalan dengan penelitian terdahulu yang menyebutkan bahwa tidak ada hubungan antara umur dan jenis kelamin dengan masalah stunting, meskipun proporsi penderita stunting terbanyak pada balita laki-laki (Setyawati, 2018).

\section{Kesimpulan dan Saran}

Berdasarkan hasil penelitian ini, variabel pendidikan ibu, jenis kelamin balita, status pekerjaan, tempat tinggal dan sarana sanitasi memiliki hubungan yang positif dan mempengaruhi kejadian balita stunting. 
Terdapat hubungan yang bermakna (signifikan) pada variabel status pekerjaan ibu, tempat tinggal, sanitasi dan status ekonomi dengan kejadian balita stunting. Dari hasil penelitian ini, penulis menyarankan perlu adanya strategi pemerintah yang tepat dan cepat dalam upaya menurunkan angka kejadian balita stunting di Indonesia. Intervensi gizi spesifik yang ditujukan kepada ibu hamil dan anak dalam 1000 Hari Pertama Kehidupan (HPK) perlu digiatkan dan disosialisasikan secara menyeluruh ke daerah perkotaan dan pelosok Indonesia. Intervensi gizi sensitif melalui kegiatan pembangunan di luar bidang kesehatan termasuk didalamnya pembangunan ekonomi masyarakat dengan target masyarakat umum masih sangat perlu ditingkatkan.

\section{Daftar Pustaka}

Adiyanti, Maya. 2014. Pola Asuh Gizi, Sanitasi Lingkungan, dan Pemanfaatan Posyandu dengan Kejasian Stunting pada Baduta di Indonesia (Analisis Data Riskesdas Tahun 2010). Depok: Universitas Indonesia.

Anindita. 2012. Hubungan Tingkat Pendidikan Ibu, Pendapatan Keluarga, Kecukupan Protein dan Zink dengan Stunting Balita Usia 6-35 Bulan di Kecamatan Tembalang, Kota Semarang. Jurnal Kesehatan Masyarakat Universitas Diponogoro. 1(2): 617 626

Anisa, Paramitha. 2012. Faktor yang Berhubungan Dengan Kejadian Stunting Pada Balita usia 25-60 Bulan di Kelurahan Kalibaru Depok tahun 2012. Skripsi 85. Depok: Universitas Indonesia

Atikah, Rahayu, .et al. 2014. "Risiko Pendidikan Ibu Terhadap Kejadian Stunting Pada Anak 6-23 Bulan.” Penel Gizi Makan 129-136.

Bintarto. 1983. Interaksi Desa - Kota. Jakarta: Ghalia. Devi, Mazarina. 2010. Analisis Faktor-Faktor yang Berpengaruh Terhadap Status Gizi Balita di Pedesaan. Teknologi dan Kejuruan. 33(2): 183-192.

Diana, Fivi Melva. 2006. Hubungan Pola Asuh dengan Status Gizi Anak Batita di Kecamatan Kuranji Kelurahan Pasar Ambacang Kota Padang Tahun 2004. Jurnal Kesehatan Masyarakat Andalas. 1(1): 19-23.

Ernawati, Aeda. 2003. Hubungan Faktor Sosial Ekonomi, Higiene Sanitasi Lingkungan, Tingkat Konsumsi dan Interaksi dengan Status Gizi Anak Usia 2-5 tahun di Kabupaten Semarang. Tesis. Semarang: Universitas Diponegoro.

Faradina, Rizka., et al. 2018. Analisis Faktor-Faktor yang Mempengaruhi Pengeluaran Konsumsi Pangan Rumah Tangga (Studi Kasus : Desa Karang Gading, Kecamatan Secanggang, Kabupaten Langkat). TALENTA Conference Series. 1(1): 284-295.

Fikrina., et al. 2017. Hubungan Tingkat Sosial Ekonomi dengan Kejadian Stunting pada Balita Usia 24-59 Bulan Di Desa Karangrejek Wonosari Gunung Kidul. Universitas Aisyiyah Yogyakarta.

Junaidi. 2015. Model Regresi Binary Logit (Aplikasi Model dengan Program SPSS. Diakses pada: October 2018. <https://www.researchgate.net/publication/278093773_Model_Regresi_Binary_Logit_Aplikasi_Model_dengan_Program_SPSS>.

Kemendes. 2017. Buku Saku Desa dalam Penanganan Stunting. Jakarta: Kemendes.

Kemenkes. 2015. Rencana Strategis Kementerian Kesehatan Tahun 2015-2019. Jakarta: Kemenkes RI.

Kemenkes RI. 2010. Keputusan Menteri Kesehatan No 1995/Menkes/SK/XII/2010 tentang Standar Antropometri Penilaian Status Gizi Anak. Jakarta: Kemenkes RI.

Kemenkes. 2018. Pemerintah Fokus Cegah Stunting di 100 Kabupaten/Kota. Diakses pada: April 7. September 2018. <http://www.depkes.go.id/article/view/18040700003/pemerintah-fokus-cegah-stunting-di-100-kabupaten-kota.html>

Kemenkeu. 2018. Penanganan Stunting Terpadu tahun 2018. Jakarta: Direktur Anggaran Bidang Pembangunan Manusia dan Kebudayaan.

Hasibuan, L. S., et al. 2014. Analisis Pola Pengeluaran Rumah tangga Miskin di Kabupaten Simalungun. Jurnal Ilmu Ekonomi dan Studi Pembangunan. $16(1): 38-55$.

M. Gibney, M. Barrie, John, Leonore. 2008. Gizi Kesehatan Masyarakat. EGC 217.

Monteiro., et al. 2010. Narrowing Sosioeconomic Inequality in Child Stunting. Bull World Health Organ 305-311.

Ni'mah, Cholifatun., et al. 2015. Hubungan Tingkat Pendidikan, Tingkat Pengetahuan dan Pola Asuh Ibu dengan Wasting dan Stunting Pada Balita Keluarga Miskin. Media Gizi Indonesia. 10(1): 84-90.

Ramli., et al. 2009. Prevalence and Risk Factors for Stunting and Severe Stunting Among Under-Fives in North Maluku Province of Indonesia. BMC Pediatrics. 9(1): 64 .

Republik Indonesia. 1992. Undang Undang Kesehatan No. 23 tahun 1992 pasal 22. Jakarta: Kemenkes RI. Riskesdas. 2018. Jakarta: Balitbangkes Kemenkes. 
Riskesdas. 2010. Laporan Hasil Riset Kesehatan Dasar. Jakarta: Kementerian Kesehatan RI.

Rosha., et al. 2012. Analisis Determinan Stunting Anak 0-23 bulan pada daerah miskin di Jawa Tengah dan Jawa Timur. Penel Gizi Makan. 34-41.

Rukmana, Erni et al. 2016. Faktor Resiko Stunting Pada Anak Usia 6-24 Bulan di Kota Bogor. JURNAL MKMI. 12(3): 192-199.

Sandjaja. 2008. Kajian Perbedaan Prevalensi Balika Kurus dan Pendek Menurut Standar WHO 2005 dibanding NCHS: Analisis Data SKRT 2004. Gizi Indon 31(1):9-22.

Setyawati, V.A.V. 2018. Kajian Stunting Berdasarkan Umur dan Jenis Kelamin di Kota Semarang. University Research Colloqium 837.

TNP2K. 2018. Gerakan Nasional Pencegahan Stunting dan Kerjasama Kemitraan Multi Sektor. Jakarta: Sekretariat Wapres RI.

UNICEF. 2012. Malnutrition in Number. UNICEF Annual Report.

UNSCN. 2004. Fifth Report on The World Nutrition Situation. SCN.
Vidmar, Suzana., et al. 2004. Standardizing anthropometric measures in children and adolescents with new functions for egen. The Stata Journal. 4(1): 50-55. Lestari, W., et al. 2014. Faktor risiko stunting pada anak umur 6-24 bulan di kecamatan Penanggalan kota Subulussalam provinsi Aceh. Jurnal Gizi Indonesia. 3(1): 37-45.

WHO. 2012. Annual Report. Diakses pada: September 2018 <https://corporate.target.com/_media/ TargetCorp/annualreports/content/download/ pdf/Annual-Report.pdf?ext=.pdf>

Wiyogowati, Citaningrum. 2012. Kejadian Stunting pada Anak Berumur Dibawah Lima Tahun (0-59 bulan) Di Provinsi Papua Barat Tahun 2010 (Analisis Data RISKESDAS 2010). Kesehatan Masyarakat. World Bank Group. 2016. World Bank investing in Early Years Brief. Washington DC: World Bank.

Yudaningrum, Agnes. 2011. Analisis Hubungan Proporsi Pengeluaran dan Konsumsi Pangan Dengan Ketahanan Pangan Rumah Tangga Petani di Kabupaten Kulon Progo. Surakarta: Fakultas Pertanian. Universitas Sebelas Maret. 